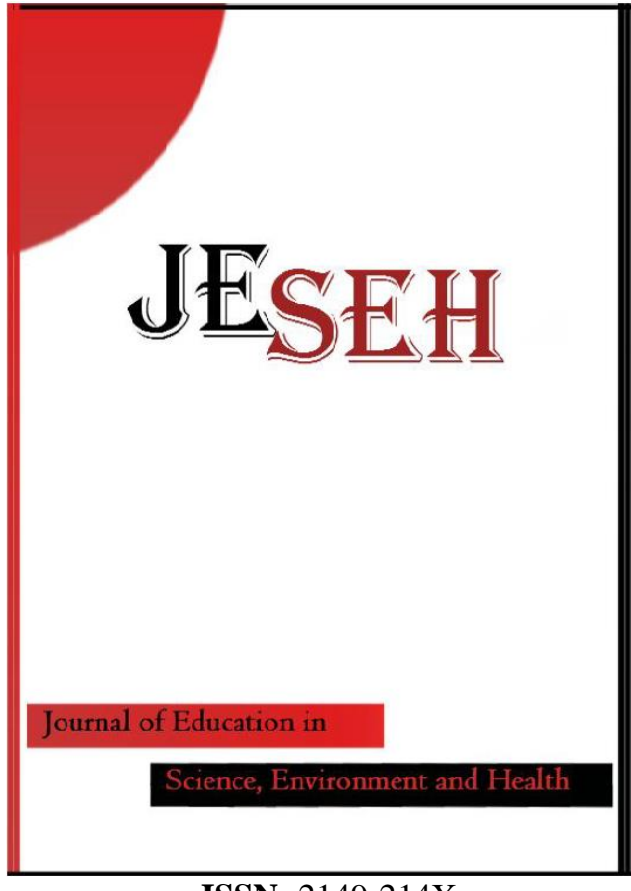

ISSN: $2149-214 \mathrm{X}$

\section{Journal of Education in Science, Environment and Health}

www.jeseh.net

Examining Science Teachers' Decisions about Nuclear Power Plants from the Perspective of Normative Decision Theory

Nurhan Ozturk, Esra Bozkurt Altan

Sinop University

To cite this article:

Ozturk, N. \& Bozkurt Altan, E. (2019). Examining science teachers' decisions about nuclear power plants from the perspective of normative decision theory. Journal of Education in Science, Environment and Health (JESEH), 5(2), 192-208. DOI:10.21891/jeseh.581739

This article may be used for research, teaching, and private study purposes.

Any substantial or systematic reproduction, redistribution, reselling, loan, sub-licensing, systematic supply, or distribution in any form to anyone is expressly forbidden.

Authors alone are responsible for the contents of their articles. The journal owns the copyright of the articles.

The publisher shall not be liable for any loss, actions, claims, proceedings, demand, or costs or damages whatsoever or howsoever caused arising directly or indirectly in connection with or arising out of the use of the research material. 


\title{
Examining Science Teachers' Decisions about Nuclear Power Plants from the Perspective of Normative Decision Theory
}

\author{
Nurhan Ozturk, Esra Bozkurt Altan
}

\begin{tabular}{|c|c|}
\hline Article Info & Abstract \\
\hline Article History & \multirow{9}{*}{$\begin{array}{l}\text { This study aimed to determine science teachers' decisions about the socio- } \\
\text { scientific issue of nuclear-power plant and how these decisions are given within } \\
\text { the framework of the decision making process. The design of this research is } \\
\text { based on a case study. } 22 \text { teachers who worked in the middle schools in the city } \\
\text { center of the province of Sinop were recruited for the study. The data were } \\
\text { collected through the semi-structured interviews. The data obtained through } \\
\text { these interviews were analyzed qualitatively. For the analysis of the data the } \\
\text { opinions of the teachers were discussed according to the steps of the decision- } \\
\text { making process based on normative decision theory. The knowledge levels of } \\
\text { science teachers about nuclear power plants were mostly found to be partially } \\
\text { sufficient. It has been determined that science teachers evaluate the socio- } \\
\text { scientific issues of nuclear power plants mostly with the dimensions of economy } \\
\text { and environment. }\end{array}$} \\
\hline Received: & \\
\hline 04 February 2019 & \\
\hline $\begin{array}{l}\text { Accepted: } \\
\text { 29 June } 2019\end{array}$ & \\
\hline Keywords & \\
\hline Decision-making & \\
\hline Nuclear power & \\
\hline Science teachers & \\
\hline Socio-scientific issues & \\
\hline
\end{tabular}

\section{Introduction}

With the advancement of science and technology, human activities have led to social, ethical and moral conflicts (Lee \& Witz, 2009). These developments may affect the multi-dimensional thinking and decisions of individuals, and this may undoubtedly affect the future of societies in many aspects such as economic, political and environmental. Many issues such as cloning, global warming, gene therapy, stem cells, organ donation, alternative fuels, GMOs (Genetically Modified Organisms), chicken meat, surrogacy, abortion, hydroelectric power plants, nuclear power plants, etc. cause people to be on the horns of a dilemma because of economic, political or environmental reasons and are considered as controversial subjects (Chang Rundgren \& Rundgren, 2010; Presley et al., 2013; Sadler \& Zeidler, 2004; Sadler \& Zeidler, 2005; Sadler \& Donnelly, 2006; Sadler, 2004; Topcu, Sadler \& Y1lmaz-Tuzun 2010; Wu \& Tsai, 2012). Constituting a dilemma in individuals, these issues are defined as socio-scientific issues (SSIs) since they are at the intersection of both social and scientific dimensions (Sadler, 2004). SSIs are complex, open-ended and controversial subjects with no simple and single solution (King \& Kitchener 2004; Kolstø 2001). At the same time, the SSI provides a forum for discussion about the current science and technological developments through their social, scientific, political, economic and ethical dimensions (Chang Rundgren \& Rundgren, 2010; Eggert et al., 2013; Sadler, Barab \& Scott, 2007; Zeidler et al., 2005). SSIs don't have any complete and right solution. SSIs are always open to different solutions since it may involve a positive or negative approach (Kolstø, 2001; Sadler, 2009; Zohar \& Nemet, 2002). SSIs also include the aspects of having local, regional and global dimensions from social and political perspectives and offering topics from real life (Ratchliffe \& Grace 2003).

\section{Nuclear Power Plants as a Socio-Scientific Issue}

Nuclear energy is defined as the energy arising from the disintegration of the atomic nucleus. The nuclear power plant is a plant that generates electricity using radioactive materials as fuel through one or more nuclear reactors. The concept of a nuclear power plant is an issue that is on the front burner because it is planned to be established in cities such as Sinop, Mersin in Turkey and that the process of the agreement is broadcasted on media. The concept of nuclear power/nuclear power plant is known to our citizens mostly by the Chernobyl accident, which occurred in 1986 and caused severe damage. After this accident, the perception of the nuclear plant as being a risk against health and environment is developed in the society. Similarly, the nuclear accident that occurred in Fukushima in 2011 made individuals more sensitive to the health and environment aspects of the problems arising from nuclear energy (Ramana, 2011). There are ongoing works related to Akkuyu Nuclear Power Plant (in Turkey) the foundation of which was laid in 2018 following the agreement that was signed between Russia and Turkey in 2010 and which forms the basis of an important discussion in our country in the 
recent years and to Sinop Nuclear Power Plant (in Turkey) which was signed between Japan-France partnership in 2013 .

The issue of nuclear power plant draws the attention of the public in terms of social and sustainable development and constitutes an important context in terms of its effects (Jho, Yoon \& Kim, 2014). It is important that individuals become aware of these current issues related to science, technology and society and make informed decisions (Bossér et al., 2015; Chang \& Chiu, 2008; Eggert \& Bögeholz, 2010). Kolstø et al. (2006) who point out that it is difficult to make decisions about SSIs, emphasize the need to consider many dimensions such as political, ethical, scientific during the decision process. It is important to make judgments and analytical decisions taking into account many of the dimensions of these multi-dimensional issues. There are researchers that take into consideration the related attitude and point of views of the pre-service science teachers (e.g. Ates \& Saracoğlu, 2013; Cansız \& Cansız, 2015; Ercan, Ural \& Tekbıyık, 2015; Eş, Işık Mercan \& Ayas, 2016; Evren Yapıcığlu \& Aycan, 2018; Kapici \& Ilhan, 2016; Özdemir \& Çobanoğlu, 2008; Özdemir, 2014; Yener, Aksüt \& Somuncu Demir, 2017), teachers (Kenar, 2013; Lee \& Yang, 2013) and students (Jho et al., 2014; Wu \& Tsai, 2007; Yang \& Anderson, 2003) towards nuclear power plants. A limited number of research was conducted with teachers (Kenar, 2013; Lee \& Yang, 2013). The researchers conducted with preservice teachers and teachers in relation to the study group of this research are as follows.

In the research that they have realized with pre-service science teachers, Ates \& Saracoğlu (2013) have found out that most of the pre-service teachers have positive considerations in relation to nuclear energy in terms of generating electricity and energy, and providing prestige. It has been found out that the pre-service teachers who have negative considerations about nuclear energy have given apprehensive answers because of problems such as dangerous weapon production, possible serious accidents, cancer and radioactive leak. Cansiz \& Cansiz (2015) have made a research on the views of pre-service science teachers studying in Ankara in relation to the Akkuyu nuclear plant and reported that pre-service teachers have a negative opinion in relation with the establishment of a nuclear power plant in Turkey. In their study that has been conducted with pre-service science and social studies teachers, Kapici \& Ilhan (2016), have found out that pre-service teachers are not knowledgeable about the working principle of the nuclear power plant; but that pre-service social studies teachers have a positive attitude towards nuclear energy whereas pre-service science teachers have a more negative attitude. In their study; Eş, Işık Mercan \& Ayas (2016) have investigated the knowledge and opinions of pre-service teachers who have been continuing their education in different departments in Sinop. In the study, it is concluded that the pre-service teachers have limited knowledge about nuclear energy, that their information resource is the media, that the pre-service teachers do not want to live in a province where there is nuclear energy and that the number of positive and the number of negative opinions on the establishment of nuclear power plant in Turkey are close to each other. Evren Yapıcıoğlu \& Aycan (2018) have investigated the effect of the socio-scientific issue-based instructional activities related to the Nuclear Energy Plants (NEP) that have been attempted to be made widespread in Turkey on the pre-service science teachers' decisions, positions and types of informal reasoning they use while making their decisions. In this study it was found that while making their decisions, before the application, they were mostly engaged in the ecology-based informal reasoning; after the application, they mostly utilized the social type of informal reasoning. Lee \& Yang (2013) have examined the attitudes of high school technology teachers towards nuclear energy. It has been concluded that the technology teachers in Taiwan are interested in the news about the disaster that occurred in Fukushima, Japan and that they have less support for the growing nuclear plant establishment in Taiwan and that they prefer the use of renewable energy sources such as wind and sun instead.

The above-mentioned researchers provide the approaches of teachers and pre-service teachers who face or don't face the nuclear energy in real life, about the nuclear energy issue, taking into consideration these approaches in relation to various variables. An important issue with the SSIs is how these decisions are made when developing positive or negative approaches. In fact, various researchers determined that participants' knowledge of the nuclear power plant is incomplete, but they still have positive or negative opinions on the matter (Eş et al., 2016; Özdemir \& Çobanoğlu, 2008). In this context, it is crucial to investigate how individuals decide in relation to the SSIs.

\section{Decision Making and Socio-Scientific Issues}

The fact that it includes different solutions and that it can have a different understanding when it is viewed from different dimensions such as ethics, environment and economy makes it inevitable for the SSIs to be controversial (Levinson, 2008; Zeidler, 2014). For this reason, methods such as classroom discussion and debates are often preferred when planning teaching processes in which the SSIs are in focus (Acar, Turkmen \& 
Roychoudhury, 2010; Levinson, 2006; Zeidler et al., 2005). Deciding on these issues that do not have a single correct solution requires taking into account specific criteria and constraints and considering their relative importance. In this manner, the discussion of the SSIs in a class alone will be insufficient. Another aspect which is as vital as re-considering these issues is to make a decision. In other words, it is essential for students to reach a decision as a result of reconsideration, and it is necessary to include the practices that will employ the decision-making processes in the classes.

The execution of the decision-making process requires the existence of a problem statements' that includes more than one alternative (Svenson, 1996). In this case, the decision is made depending on the problem statement. In the literature, there are different approaches directed at explaining the decision-making process (Lipshitz, Klein, Orasanu \& Salas, 2001; Ratcliffe, 1997). One of these approaches explains decision-making with two approaches: normative/analytical and summative. The holistic decision theory focuses on studying the intuitive and psychological processes while concentrating on how the decision is made. According to this theory, past experiences of people or other psychological factors influence decision-making. Normative decision theory focuses on how the decisions should be made rather than how they are made (Hansson, 2005; Jonassen, 2012; Ratcliffe, 1997).

According to this perspective in normative decision theory, the psychological processes that affect decisionmaking are ignored, and it is focused on how to make the best decision (Hong \& Chang, 2004). Similarly, Hogarth (2005) explains the decision-making process through two different cognitive systems, being intuitive and analytical. While defining the intuitive decision-making system as unconscious and influenced by emotions, he points out that the analytical system requires consciousness and logical justification.

The individuals who are faced with the SSIs, which allow the operation of decision-making processes by their nature, will be influenced by their previous experiences, practices or mental models in their decision-making process (Fang, Hsu \& Lin, 2018). However, when the teaching process of these subjects is structured to require analytical decision-making, individuals will tend to make analytical decisions even though the intuitive system will affect the decision-making mechanism. It is possible to understand the reasons behind the individuals' decisions about the SSIs through theories directed at the decision-making process (Wu \& Tsai, 2007; 2011).

Normative decision-making theory allows dealing with decision-making as a process (Germeijs \& De Boeck, 2003; Kortland, 1996). The decision-making process starts with the "defining the problem" (Lunenburg, 2010). At this step, it is necessary to examine the problem in depth and determine the features that the problem should have in order to obtain the best solution. Then, in the step of "creating alternatives", possible alternatives are investigated in order to solve the problem. The in-depth research of this step and the effect of each alternative on the outcome will affect the decision process. The next step is "evaluation of the alternatives". At this step, the solutions are expected to be evaluated within the framework of the criteria determined in the first step (Kortland, 1996; Ratcliffe, 1997). At this step, individuals evaluate each alternative within the framework of previously determined criteria and decide the most suitable alternative to solve the problem (Ratcliffe, 1997). Often, none of the alternatives may be sufficient to meet all the criteria (Baker et al., 2001). For this reason, different tools are referred to help decision-making at these steps (Hansson, 2005). Decision matrices, SWOT analysis, force field analysis (Jonassen, 2012), advantage-disadvantage assessment, analytical hierarchies (Baker et al., 2001) are some of these tools. For the decision-making process that may be considered to end with the "most suitable alternative", Lunenburg (2010) has included two more steps being "the implementation of the decision" and "the evaluation of the effectiveness of the decision". Depending on the results of their choice, the person has the opportunity to evaluate their success in the activities they perform during the process (Ratner \& Herbst, 2004). In this way, even the decisions that are concluded negatively can be turned into an achievement for the decision making process that will continue during lifetime (Gauld, 2005; Raeva, Dijk \& Zeelenberg, 2011).

In this research, how SSIs are decided is discussed in the context of normative decision-making theory, because it is important to determine whether individuals have a rational point of view towards the issue. Defining the problem phase of normative decision making can be considered as the stage in which the socio-scientific issue is understood. "Creating alternatives" and "evaluations of the alternatives" steps relate to what aspects can be addressed when evaluating the socio-scientific issue. "Determining of the most suitable alternative" step provides insight into how the decision is consistent with the dimensions discussed in the evaluation process. Such an assessment will enable individuals to determine which aspects of the issue they are taking in the decision-making process in relation to SSIs and to decide which of these dimensions is more important in making their decisions. This is important in order to conduct a more in-depth analysis beyond the determination of what is effective in the final decision. Therefore, in this research, an evaluation is made within the scope of normative decision making theory in order to examine the decisions about SSIs in depth. 
The "decision making" skills that is among the 21st-century skills commonly defined by many international organizations and also that is among the life skills in the science curriculum in Turkey is an important skill defined in the framework of science literacy, which is the main objective of science education programs (MoNE, 2018). Various researchers point out that dealing the SSIs with suitable learning-teaching processes in science courses can provide an important context for students to improve their decision-making skills (e.g. Barrue \& Albe, 2013; Jho, et al., 2014; Jime'nez-Aleixandre, 2002; Patronis, Potari \& Spiliotopoulo, 1999; Sadler \& Zeidler, 2005). In our country, however, there are findings about affecting the decision-making processes of students in the learning-teaching process in the studies on nuclear power plant (K1lınç, Stanisstreet \& Boyes, 2013; Tekbiyik, 2015). Kilinc et al. (2013) aimed to determine the opinions of secondary school students about nuclear power plants planned to be constructed in Turkey. In the research, students have expressed that nuclear power plant in decision-making processes was beneficial with the contribution to the national economy and meeting the energy needs. However, students have indicated about that nuclear power plant is to be risky because of damage to the environment and global warming. In addition, socio-scientific based learning environments could include the trust in knowledge sources, the evaluation of current data regarding the risks of suggested technology, values, biases and cultural variables, gender roles in decision making processes. And this contributes to the evaluation of decision alternatives (such as benefit / risk) (Kılınç et al., 2013). Tekbiyik (2015) examined the opinions and decision-making processes of pre-service science teachers on nuclear power plant in the process of cooperative learning in his study. In this research, it is concluded that scientific literacy, knowledge acquired during the process of cooperative learning, awareness and content knowledge on the subject are effective in the decision-making processes related to the SSIs. Unlike these studies, in present study, it is tried to determine the case of reflect the teachers' decisions about the nuclear power plant analytical decision process.

\section{Research Focus}

The nuclear power plant project which is planned to be established in Sinop city of Turkey and on which the studies are accelerated is an SSI which some of the people in the province support, some of them do not support or remain undecided. As a matter of fact, the reaction of the public towards the nuclear power plant to be established in Sinop has sometimes appeared on media. In this case, it is considered necessary that science teachers working in this province have a decision about the subject and can explain this decision through a justification. As a matter of fact, the role of teachers in making students consider all aspects of the SSI and in raising them as science literate individuals by preparing learning environments that will develop students' decision-making skills cannot be denied. In this direction, it is the issue of concern of this research to reflect the analytical decision process of the teachers' decisions about the nuclear power plant which is a socio-scientific issue compatible with the context of the province where they live. The analytic (normative) decision-making theory focuses on how decisions should be made (Hansson, 2005; Jonassen, 2012; Ratcliffe, 1997).

Science teachers are expected to prepare a learning environment that will enable students to discover the multidimensional nature of SSI and improve their decision-making skills regarding these matters. Therefore, studying the ability of teachers themselves to approach the nuclear plant SSI from multiple perspectives and make decisions based on an analytical decision-making process rather than personal tendencies is important for the contribution it will make to the literature. It is also believed that the fact that the present research addresses with a phenomenological approach the decisions that science teachers who live in a province that involves a nuclear plant issue make about this issue will make a contribution to the literature in terms of revealing the analytic decision-making capabilities of the teachers who experience this phenomenon. The purpose of this research is to examine the decisions of the science teachers in relation to the socio-scientific issue of the nuclear power plant and how these decisions are made in the context of the steps of the decision-making process.

\section{Method}

The qualitative paradigm is taken as the basis for determining the study group, the data collection process and the analysis of the data in order to examine the decisions of science teachers in relation to the socio-scientific issue of nuclear power plant and how they have made these decisions in the context of the steps of the decisionmaking process. The design of research design is phenomenology. Because, the focus of this study is to investigate the decisions of science teachers living in Sinop, which is a city planned to build a nuclear power plant, about nuclear energy and the reasons for decisions. Phenomenologists focus on describing what all participants have in common as they experience a phenomenon (Creswell, 2007). 


\section{Participants}

The SSIs are considered as concerning the society, controversial, up-to-date, subject to the decision-making of the individual, and are emphasized. The information, decisions of the science teachers' who take the responsibility of raising individuals who are able to make conscious decisions and who are engaged in occupying the agenda, about the nuclear energy that is planned to be established in the cities they live in and how they make this decision have a significance. This is taken into consideration in determining the study group, and 22 science teachers (ST) (14 female, 8 male) working in all the secondary schools in the central district of Sinop province are included in the study based on purposeful sampling technique (Creswell, 2012). The STs consisting the study group have an experience of 15 years or more $(f=11), 6-10$ years $(f=6), 1-5$ years $(\mathrm{f}=3)$ and $11-15$ years $(\mathrm{f}=2)$ respectively. 11 of the teachers are graduated from science education, and 5 of them have a bachelor's degree in physics-chemistry-biology teaching. 6 teachers are graduated from the department of chemistry in the science faculty and received pedagogical formation. All of the STs have been working in Sinop province at least for 4 years.

\section{Data Sources and Procedures}

The data source of the study is the Nuclear Power Plant Interview Form (NPPIF) developed by the researchers. NPPIF is designed to determine the resources that teachers apply when making decisions about their definitions, decisions and reasons in relation to nuclear energy. In order to determine the comprehensibility and relevance of the form, it is presented to two science education experts who have researchers related to the SSI; and after receiving their positive opinion, the two science teachers have been interviewed. Together with the feedback received following the interview with the teachers, the form has taken its final form. The data of the study have been obtained by semi-structured interviews with the STs. In semi-structured interviews, questions were prepared before the interview, but changes can be made during the interview, questions can be asked confidently, and all questions can be used flexibly (Merriam, 2009). During the data collection process, each science teacher is interviewed for 20 minutes on a pre-determined date and time, and their voice is recorded with their permission.

\section{Data Analysis}

Normative decision-making theory allows dealing with decision-making as a process (Germeijs \& De Boeck, 2003; Kortland, 1996). The decision-making process starts with the "identifying the problem" (Lunenburg, 2010). At this step, it is necessary to examine the problem in depth and determine the features that the problem should have in order to obtain the best solution. Then, in the step of "generating alternatives", possible alternatives are investigated in order to solve the problem. The in-depth research of this step and the effect of each alternative on the outcome will affect the decision process. The next step is "evaluating alternatives". At this step, the solutions are expected to be evaluated within the framework of the criteria determined in the first step (Kortland, 1996; Ratcliffe, 1997). At this step, individuals evaluate each alternative within the framework of previously determined criteria and decide the most suitable alternative to solve the problem (Ratcliffe, 1997). Often, none of the alternatives may be sufficient to meet all the criteria (Baker et al., 2001). For this reason, different tools are referred to help decision-making at these steps (Hansson, 2005). Decision matrices, SWOT analysis, force field analysis (Jonassen, 2012), advantage-disadvantage assessment, analytical hierarchies (Baker et al., 2001) are some of these tools. For the decision-making process that may be considered to end with the "choosing an alternatives", Lunenburg (2010) has included two more steps being "implementing the decision" and "evaluating decision effectiveness". Depending on the results of their choice, the person has the opportunity to evaluate their success in the activities they perform during the process (Ratner \& Herbst, 2004). In this way, even the decisions that are concluded negatively can be turned into an achievement for the decision making process that will continue during lifetime (Gauld, 2005; Raeva et al., 2011).

The data obtained through these interviews were analyzed qualitatively. In the analysis process, naming is made for each Science Teacher (as an example, the first teacher was renamed as ST1). The opinions of each ST are transferred to the computer environment, and the answers of the teachers are read separately by two researchers. Each teacher's answer sheet was read separately in order to code the potential concepts and thematic structures in short and the coding process was based on either just words or whole sentences (Bogdan \& Biklen, 2007; Gay, Mills \& Airasian, 2006). The data analysis is predicated on the reflection of the decision-making process steps based on the normative decision theory of the teachers. The decision-making process consists of the steps such as identifying the problem, generating alternatives, evaluation alternatives, choosing an alternative, 
implementing the decision and evaluating decision effectiveness. As the implementation and evaluation steps of the decision are suitable for evaluation in the longer term, the process is considered the first 4 steps. After the opinions of the teachers are read by the researchers, it is discussed in which steps of the decision-making process the included opinions will be taken under consideration.

Table 1. Partial framework for evaluating teachers' opinions according to the steps of the decision-making process.

\begin{tabular}{ll}
\hline Steps of decision making process & Related findings \\
\hline Identifying the problem & Information on nuclear power plants \\
$\begin{array}{l}\text { Generating alternatives } \\
\text { Evaluation alternatives }\end{array}$ & $\begin{array}{l}\text { Expressing the aspects of nuclear energy } \\
\text { and nuclear power plant related to } \\
\text { positive / negative aspects and making } \\
\text { explanations }\end{array}$ \\
Choosing an alternative & $\begin{array}{l}\text { Teachers' decisions and justifications } \\
\text { based on their decisions }\end{array}$ \\
\hline
\end{tabular}

In order to identifying the problem of the decision-making process, the definitions of teachers in relation to nuclear energy are taken under consideration in three different categories being insufficient, partially sufficient and sufficient. These criteria were created by the researchers based on similar structure in the study of Öztürk and Yenilmez Türkoğlu (2018). In this context, the criteria used in making the insufficient, partially sufficient and sufficient classification are presented in table 2.

Table 2. Criteria for evaluation of teachers' definitions in relation to nuclear energy.

\begin{tabular}{ll}
\hline Evaluations & Criteria \\
\hline Insufficient & $\begin{array}{l}\text { Not responded, no scientific explanation, } \\
\text { completely wrong description or use of a faulty } \\
\text { example }\end{array}$ \\
Partially Sufficient & $\begin{array}{l}\text { Descriptions such as generating energy from } \\
\text { nuclear material, generating energy from the atom } \\
\text { (without describing how it is generated, without } \\
\text { using scientific language) }\end{array}$ \\
Sufficient & $\begin{array}{l}\text { Benefiting from the energy that arises while } \\
\text { splitting the nuclear materials or descriptions } \\
\text { related to the power plants working principle } \\
\text { through different descriptions having the same } \\
\text { meaning (using scientific language) }\end{array}$ \\
\hline
\end{tabular}

The definitions of the teachers are subjected to descriptive analysis by the two researchers, and their descriptions are evaluated based on the criteria presented in Table 2 . The reliability of the data analysis was calculated by using Miles and Huberman (1994) proposed formula (Reliability of the data analysis= [Same opinions / (Same opinions + Different opinions)]). For the reliability of the data analysis, the two researchers' opinions and differences of opinion were determined and the reliability percentage was calculated as $91 \%$. Then, researchers compared the results of the analysis and then interpreted together, then a specialist who has researchers on nuclear energy examined the latest version of the analysis that presents the teachers' descriptions and in which table they are classified, and the analysis process is completed.

Themes are determined by taking into account the science, policy, economy, society, ethics and environmental aspects (Chang Rundgren \& Rundgren, 2010) of the SSIs presented in Figure 1 to assess the teachers' awareness of the positive / negative aspects of nuclear energy in the process of creating alternatives in the decision-making process. 


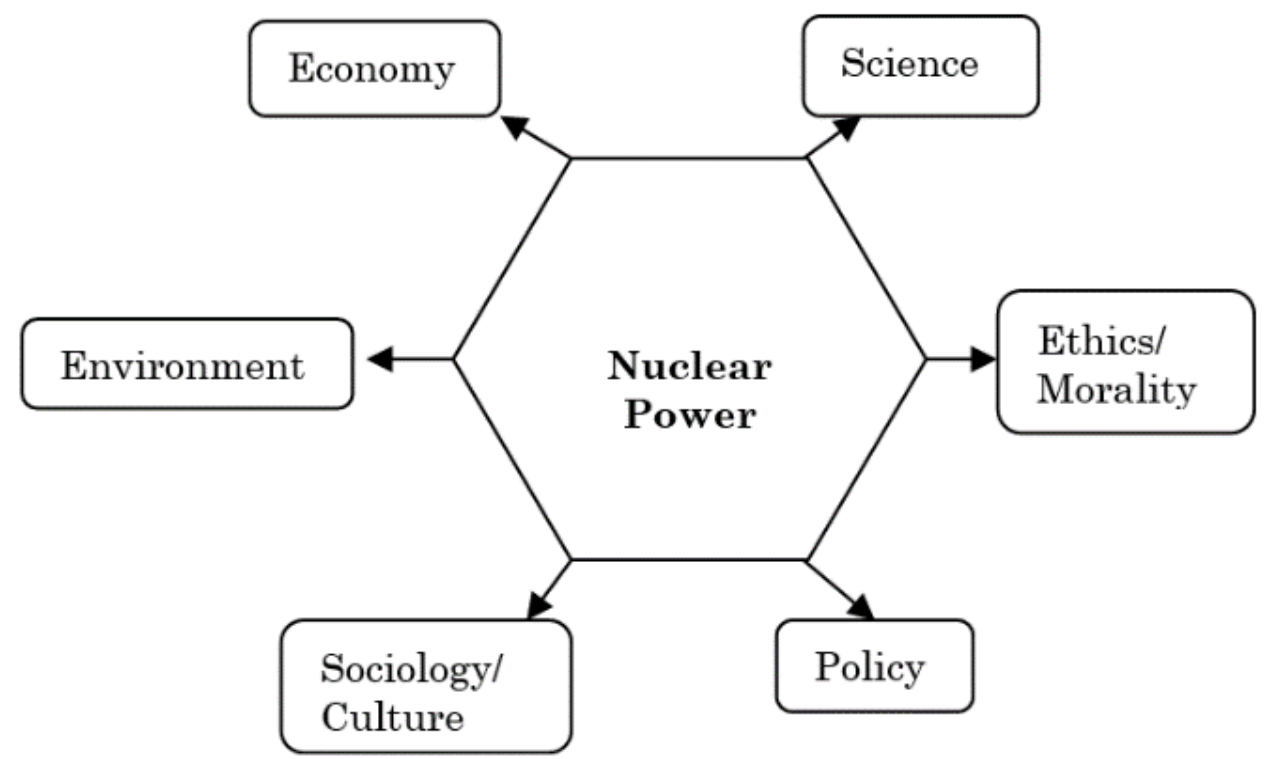

Figure 1. Aspects of socio-scientific issues

Sample codes for this analysis are presented in table 3.

Table 3. Sample code and descriptions.

\begin{tabular}{lll}
\hline Dimension & Code & Sample views \\
\hline Social & Health & $\begin{array}{l}\text { "The positive side of the nuclear is the generation of energy, but it has } \\
\text { higher risks. Even in the case of a leak at the minimum level, it may } \\
\text { endanger the human health" (ST1) }\end{array}$ \\
Economy & Development & $\begin{array}{l}\text { "Think about it we will cover this much of energy deficit, we will } \\
\text { generate cheaper energy, and it seems like a must in order for the } \\
\text { country to gain power..."(ST21) }\end{array}$ \\
\hline
\end{tabular}

The teachers' decision expression that are defined as positive for establishment of the nuclear power plant or negative for establishment of the nuclear power plant and their justifications in relation to these decisions are taken under consideration in order to evaluate the alternatives of the decision making process and the data in relation to the steps to determine the most suitable alternative. Two different researchers have examined the emphasis of the teachers regarding the related dimensions about SSIs in their decisions and justifications. For the reliability of the data analysis (according to Miles and Huberman, 1994), the two researchers' opinions and differences of opinion were determined and the reliability percentage was calculated as $96 \%$.

\section{Limitations}

The research is limited to those teachers who have experience on the socio-scientific issue of the nuclear plant that is planned to be built in Sinop, Turkey. An interview was made to reveal the decisions of the teachers about the nuclear plant socio-scientific issue and an interview form was prepared. Interview form is designed to determine the resources that teachers apply when making decisions about their definitions, decisions and reasons in relation to nuclear energy. The questions contained in the form were asked to the teachers and their decisions about nuclear plants were questioned in a general way. The socio-scientific issue about the nuclear plant was not structured within the context of a problem. The data of the research were analysed with the analytic decision-making perspective. Therefore, the findings are limited to the analytic decision-making perspective. 


\section{Ethical Consideration}

Before starting the data collection process of the research, the teachers were briefed about the subject matter. They participated in the study voluntarily. The semi-structured interviews made with them were recorded with a sound recording device after obtaining their permission for this. The interviews were made in our environment where the teachers could express themselves comfortably. There was no one other than the researchers and the teacher being interviewed in the environment. The data of the research were kept where no one could access them. No one other than the researchers listened to the records. The names of the teachers were kept secret in the research process.

\section{Results}

The definitions of the science teachers about nuclear power plants, their opinions on the positive and negative aspects of nuclear power plants and their decisions on nuclear power plants and also the factors affecting these decisions are presented within the context of the steps of the decision-making process.

\section{Identifying the Problem in Decision-Making Process: Findings on the Information of SSIs in Relation to the Nuclear Power Plants}

The findings related to the definitions of teachers in relation to the nuclear energy and nuclear power plants are presented in table 4.

Table 4. The findings related to the definitions of teachers in relation to the nuclear energy

\begin{tabular}{|c|c|c|}
\hline Code & $\begin{array}{l}\text { Frequency } \\
\text { (f) }\end{array}$ & Sample Descriptions \\
\hline Sufficient & $\begin{array}{c}7 \\
\text { (ST2,ST3,ST4,ST } \\
\text { 10,ST14,ST19,ST } \\
20)\end{array}$ & $\begin{array}{l}\text { ST2: "....The nuclear power plant can be defined as the release of very } \\
\text { powerful energy depending on the half-life of radioactive materials and } \\
\text { the conversion of this energy into electrical energy..." } \\
\text { ST10: "...It is generating electrical energy by evaporating the water using } \\
\text { the high energy that is formed while splitting the radioactive materials and } \\
\text { by covering it with high-pressure turbines ..." } \\
\text { ST14: "...It is the destabilization of the nucleus by bombing a very heavy } \\
\text { atom with particle bombing. As a result, fission reaction is realized and } \\
\text {...turbines are turned, and electrical energy is obtained..." }\end{array}$ \\
\hline Partially & 15 & ST5: “...Generating electrical energy from atom energy... \\
\hline Sufficient & $\begin{array}{c}\text { (ST1,ST5,ST6,ST } \\
\text { 7,ST8,ST9,ST11,S } \\
\text { T12,ST13,ST15,S } \\
\text { T16,ST17,ST18,S } \\
\text { T21,ST22) }\end{array}$ & $\begin{array}{l}\text { ST6: "...Power plants established for energy that is formed as a result of } \\
\text { the atom nucleus reaction..." } \\
\text { ST7: "... Generation of electrical energy as a fuel, by nuclear reactors. } \\
\text { There will cause the generation of an unimaginably high energy at the } \\
\text { instant. This will cause the generation of the energy with the vaporization } \\
\text { of the water and the effect of the pressure with the help of the turbines..." }\end{array}$ \\
\hline
\end{tabular}

The definitions of the STs in relation to nuclear energy are mostly evaluated as partially sufficient ( $\mathrm{f}=15)$. For the definitions that are evaluated as partially sufficient, it has been found out that STs often include superficial explanations such as generating energy only from atomic energy or generating energy from nuclear materials. The definitions of some of the STs in relation to nuclear energy are considered to be sufficient ( $\mathrm{f}=7$ ). It has been found out that the STs the definitions of whom are evaluated as sufficient are able to give descriptions such as the energy released by the disintegration of nuclear materials, the radioactive materials used for nuclear energy and how the nuclear energy is converted into electrical energy and its distribution.

The Generation and Evaluation of the Alternatives in Decision-Making Process: Findings Related to Descriptions of the STs in Relation to the Negative and Positive Sides of the Nuclear Power Plants

Table 5 shows the opinions of the STs regarding the positive and negative sides of nuclear power plants and findings on which factors the SSIs are related, depending on the dimensions of the SSIs. 
Table 5. Findings related to the positive/negative considerations of the teachers in relation to the nuclear energy

\begin{tabular}{|c|c|c|c|c|}
\hline Theme & Code & $\begin{array}{l}\text { Frequency } \\
\text { (f) }\end{array}$ & Teachers & Sample Descriptions \\
\hline \multirow[t]{5}{*}{ Economy } & Energy & 15 & $\begin{array}{lr}\text { ST1, } & \text { ST2, } \\
\text { ST3, } & \text { ST5, } \\
\text { ST6, } & \text { ST8, } \\
\text { ST9, } & \text { ST11, } \\
\text { ST12, } & \text { ST13, } \\
\text { ST16, } & \text { ST18, } \\
\text { ST19, } & \text { ST21, } \\
\text { ST22 } & \end{array}$ & $\begin{array}{l}\text { ST2: "The only positive side of the nuclear } \\
\text { energy that I know is that it can generate a high } \\
\text { volume of energy..." } \\
\text { ST7: "...energy generation increases every day, } \\
\text { but you still suffer from an energy deficit. I } \\
\text { think nuclear power plants will solve this } \\
\text { problem." }\end{array}$ \\
\hline & Cost & 1 & ST13 & $\begin{array}{l}\text { ST13: "The most positive part of nuclear } \\
\text { energy is I believe it is the most economical } \\
\text { energy." }\end{array}$ \\
\hline & $\begin{array}{l}\text { External } \\
\text { dependence }\end{array}$ & 8 & $\begin{array}{l}\text { ST5, ST9, } \\
\text { ST11, ST18, } \\
\text { ST19, ST20, } \\
\text { ST21, ST22 }\end{array}$ & $\begin{array}{l}\text { ST9: "By generating nuclear energy, we can } \\
\text { become independent from foreign sources." } \\
\text { ST11: "I think it is important because it will } \\
\text { solve the ever-increasing need for energy and } \\
\text { because it will prevent us to be dependent on } \\
\text { foreign sources..." }\end{array}$ \\
\hline & Lifetime & 1 & ST12 & $\begin{array}{l}\text { ST12: "The short lifetime of the nuclear energy } \\
\text { will cause difficulties for us..." }\end{array}$ \\
\hline & Total & 25 & & \\
\hline \multirow[t]{4}{*}{ Environment } & Waste & 10 & $\begin{array}{l}\text { ST2, ST3, } \\
\text { ST4, ST9, } \\
\text { ST10, } \\
\text { ST14, } \\
\text { ST16, } \\
\text { ST18, } \\
\text { ST22 }\end{array}$ & $\begin{array}{l}\text { ST3: "...it is a very significant problem that the } \\
\text { waste doesn't decompose for a long time..." } \\
\text { ST9: “...the power plant will not accept any } \\
\text { error, there are problems in storing the } \\
\text { waste..." }\end{array}$ \\
\hline & Radiation & 6 & $\begin{array}{l}\text { ST2, ST7, } \\
\text { ST8, ST12, } \\
\text { ST15, ST17 }\end{array}$ & $\begin{array}{l}\text { ST7: "...radiation emitting risk of the } \\
\text { radioactive materials and its negative effects on } \\
\text { human beings and environment..." } \\
\text { ST12: "...radiation emission..." }\end{array}$ \\
\hline & Destruction & 10 & $\begin{array}{l}\text { ST3, ST4, } \\
\text { ST6, ST7, } \\
\text { ST10, } \\
\text { ST13, } \\
\text { ST15, } \\
\text { ST17, }\end{array}$ & $\begin{array}{l}\text { ST6: "...but it is necessary to consider a } \\
\text { dangerous and a destructive possibility..." } \\
\text { ST13: "...if attention is not paid, or if } \\
\text { necessary measures are not taken, its harm to } \\
\text { the environment will be so much higher..." }\end{array}$ \\
\hline & Total & 26 & & \\
\hline \multirow[t]{4}{*}{$\begin{array}{l}\text { Sociology/ } \\
\text { Culture }\end{array}$} & Health & 7 & $\begin{array}{l}\text { ST1, } \\
\text { ST7, } \\
\text { ST15, } \\
\text { ST17, } \\
\text { ST19, } \\
\text { ST21 }\end{array}$ & $\begin{array}{l}\text { ST1: "Even in the case of a leak at the } \\
\text { minimum level, it may endanger the human } \\
\text { health." } \\
\text { ST7: "Negative effects that it may cause on } \\
\text { human health..." }\end{array}$ \\
\hline & Staff & 4 & $\begin{array}{l}\text { ST10, ST11, } \\
\text { ST17, ST22 }\end{array}$ & $\begin{array}{l}\text { ST11: “...the fact that sufficiently equipped } \\
\text { staff cannot be trained may cause negative } \\
\text { results..." }\end{array}$ \\
\hline & Unsafe & 3 & $\begin{array}{l}\text { ST5, } \\
\text { ST16 }\end{array}$ & $\begin{array}{l}\text { ST5: "...one of the problems is that it will not } \\
\text { be secure. From various angles, it will be an } \\
\text { unsafe power plant..." }\end{array}$ \\
\hline & Total & 14 & & \\
\hline Policy & $\begin{array}{l}\text { Nuclear } \\
\text { power }\end{array}$ & 1 & ST9 & $\begin{array}{l}\text { ST9: “..to tell the truth, nuclear energy means } \\
\text { power..." }\end{array}$ \\
\hline
\end{tabular}

A large part of STs has discussed their views on the positive and negative aspects of nuclear energy regarding the environment $(\mathrm{f}=26)$ and economy $(\mathrm{f}=25)$ dimensions. STs made less frequent statements on social / cultural $(\mathrm{f}=14)$ and political $(\mathrm{f}=1)$ dimensions. The fact that STs can take nuclear energy under consideration through various dimensions shows that they can look at the subject from a variety of dimensions. It will be useful to address what they emphasize when explaining these aspects. 
When taking the nuclear energy under consideration from an economic point of view, STs have made explanations related to its characteristics a solution which can meet the energy needs $(\mathrm{f}=15)$ and reduce the dependency on foreign sources in relation to energy $(\mathrm{f}=8)$, which has a high production cost $(\mathrm{f}=1)$ and which is long-lasting $(f=1)$. Therefore, it is seen that they can look at the economy theme in a multi-faceted way. STs have dealt with their evaluations in the context of the environmental theme in terms of nuclear waste, regarding the fact that it may damage the environment $(f=10)$, cause environmental damage by increasing the water temperature $(f=10)$ and cause radiation emission in the region it is located $(f=6)$. The elements they have taken into consideration under the social theme are the facts that it could threaten public health $(\mathrm{f}=7)$, that it could be dangerous for working personnel $(f=4)$, and that they don't believe that the security $(f=3)$ factors could be provided in our country. The ST who has considered the political dimension of the issue has pointed out that the nuclear energy will provide nuclear power $(\mathrm{f}=1)$ for the country.

\section{Choosing an Alternative in Decision-Making Process: The Findings on Decisions of the STs in Relation to Establishment of a Nuclear Power Plant in Sinop}

The considerations of the STs in relation to the establishment of a nuclear power plant in Sinop and the findings in relation to the justifications that they refer while expressing these arguments are presented in table 6.

Table 6. The findings about teachers' decision and the reasons for supporting teachers' decision

\begin{tabular}{|c|c|c|c|c|c|c|c|c|c|c|c|c|c|}
\hline \multirow[t]{2}{*}{ ST } & \multirow[t]{2}{*}{ Decision } & \multicolumn{2}{|c|}{ Economy } & \multicolumn{2}{|c|}{ Environment } & \multicolumn{2}{|c|}{$\begin{array}{c}\text { Sociology/ } \\
\text { Culture }\end{array}$} & \multicolumn{2}{|c|}{ Policy } & \multicolumn{2}{|c|}{$\begin{array}{l}\text { Ethics/ } \\
\text { Morality }\end{array}$} & \multicolumn{2}{|c|}{ Science } \\
\hline & & $\mathrm{D}$ & $\mathrm{AD}$ & $\mathrm{D}$ & $\mathrm{AD}$ & $\mathrm{D}$ & $\mathrm{AD}$ & $\mathrm{D}$ & $\mathrm{AD}$ & $\mathrm{D}$ & $\mathrm{AD}$ & $\mathrm{D}$ & $\mathrm{AD}$ \\
\hline ST1 & Negative & - & $\sqrt{ }$ & $\sqrt{ }$ & - & $\sqrt{ }$ & $\sqrt{ }$ & - & - & - & - & - & - \\
\hline ST2 & Negative & $\sqrt{ }$ & $\sqrt{ }$ & $\sqrt{ }$ & $\sqrt{ }$ & $\sqrt{ }$ & $\sqrt{ }$ & $\sqrt{ }$ & - & - & - & - & - \\
\hline ST3 & Undecided & $\sqrt{ }$ & $\sqrt{ }$ & - & $\sqrt{ }$ & $\sqrt{ }$ & - & - & - & - & - & - & - \\
\hline ST4 & Undecided & - & - & - & $\sqrt{ }$ & $\sqrt{ }$ & - & - & - & - & - & - & - \\
\hline ST5 & Positive & $\sqrt{ }$ & $\sqrt{ }$ & - & - & $\sqrt{ }$ & $\sqrt{ }$ & - & - & - & - & - & - \\
\hline ST6 & Negative & - & $\sqrt{ }$ & $\sqrt{ }$ & $\sqrt{ }$ & $\sqrt{ }$ & - & - & - & - & - & - & - \\
\hline ST7 & Negative & - & - & $\sqrt{ }$ & $\sqrt{ }$ & $\sqrt{ }$ & $\sqrt{ }$ & - & - & - & - & $\sqrt{ }$ & - \\
\hline ST8 & Negative & $\sqrt{ }$ & $\sqrt{ }$ & - & $\sqrt{ }$ & $\sqrt{ }$ & - & $\sqrt{ }$ & - & - & - & $\sqrt{ }$ & - \\
\hline ST9 & Undecided & - & $\sqrt{ }$ & $\sqrt{ }$ & $\sqrt{ }$ & $\sqrt{ }$ & $\sqrt{ }$ & $\sqrt{ }$ & $\sqrt{ }$ & - & - & - & - \\
\hline ST10 & Negative & - & - & $\sqrt{ }$ & $\sqrt{ }$ & $\sqrt{ }$ & $\sqrt{ }$ & $\sqrt{ }$ & - & $\sqrt{ }$ & - & - & - \\
\hline ST11 & Undecided & - & $\sqrt{ }$ & - & - & $\sqrt{ }$ & $\sqrt{ }$ & - & - & - & - & $\sqrt{ }$ & - \\
\hline ST12 & Negative & - & $\sqrt{ }$ & $\sqrt{ }$ & $\sqrt{ }$ & $\sqrt{ }$ & - & - & - & $\sqrt{ }$ & - & - & - \\
\hline ST13 & Negative & - & $\sqrt{ }$ & - & $\sqrt{ }$ & $\sqrt{ }$ & - & - & - & - & - & - & - \\
\hline ST14 & Positive & - & - & $\sqrt{ }$ & $\sqrt{ }$ & - & - & $\sqrt{ }$ & - & - & - & $\sqrt{ }$ & - \\
\hline ST15 & Negative & - & - & - & $\sqrt{ }$ & $\sqrt{ }$ & $\sqrt{ }$ & - & - & - & - & - & - \\
\hline ST16 & Undecided & $\sqrt{ }$ & $\sqrt{ }$ & $\sqrt{ }$ & $\sqrt{ }$ & $\sqrt{ }$ & - & - & - & - & - & - & - \\
\hline ST17 & Negative & - & - & $\sqrt{ }$ & $\sqrt{ }$ & $\sqrt{ }$ & $\sqrt{ }$ & - & - & $\sqrt{ }$ & - & - & - \\
\hline ST18 & Negative & - & $\sqrt{ }$ & - & $\sqrt{ }$ & $\sqrt{ }$ & - & - & - & - & - & $\sqrt{ }$ & - \\
\hline ST19 & Negative & - & $\sqrt{ }$ & $\sqrt{ }$ & $\sqrt{ }$ & $\sqrt{ }$ & $\sqrt{ }$ & - & - & $\sqrt{ }$ & - & - & - \\
\hline ST20 & Negative & $\sqrt{ }$ & $\sqrt{ }$ & - & $\sqrt{ }$ & $\sqrt{ }$ & - & - & - & - & - & - & - \\
\hline ST21 & Negative & - & $\sqrt{ }$ & $\sqrt{ }$ & - & $\sqrt{ }$ & $\sqrt{ }$ & - & - & - & - & - & - \\
\hline ST22 & Negative & $\sqrt{ }$ & $\sqrt{ }$ & - & $\sqrt{ }$ & - & $\sqrt{ }$ & $\sqrt{ }$ & - & - & - & - & - \\
\hline
\end{tabular}


In table 6, the approaches of each teacher related to the establishment of a nuclear power plant and the reasons presented in the arguments used in explaining these approaches are considered as the reasons that are effective in their decision-making. Table 6 also sets out the justification that each science teacher takes under consideration while evaluating the nuclear power plants (presented in Table 5). The purpose of this presentation is to make inferences about whether the reasons given by teachers in their evaluations are effective in their decision-making process.

While 15 of the STs have a positive understanding of the establishment of a nuclear power plant in Sinop, it has been found out that 5 are undecided and 2 have positive opinions. It has been observed that the justifications provided by the STs who have expressed their negative opinions for their decisions about the establishment of nuclear power plant do not coincide with the factors they have provided in their evaluations regarding nuclear power plants. 12 of the teachers who have provided a negative opinion (ST1, ST2, ST6, ST9, ST12, ST13, ST15, ST18, ST19, ST20, ST21 and ST22) have not taken into consideration at least one of the factors they have expressed in their evaluations on nuclear power plants. For example, ST1, while expressing his decision about the establishment of a nuclear power plant, declared reasons related to its environmental and sociocultural dimensions. However, in their general evaluations of nuclear power plants, ST1 also has made evaluations concerning its economic dimension. Three of the STs who have provided negative views have considered all the reasons that they have stated in their general evaluations of nuclear plants also during their decision-making processes. In addition, these STs have included new reasons in addition to the ones stated in their general evaluations, in their decision arguments. For example, ST7 has added evaluations on the scientific dimension in addition to the environmental and socio-cultural dimensions that he/she has considered during their general evaluations. It has been found out that one (ST5) of the 2 STs who have expressed positive views on the establishment of a nuclear power plant in Sinop has considered all the justifications that he/she has discussed in his/her general evaluations also in his/her decision justifications, and that the other one (ST14) have not considered one of the justifications during the decision step but added an evaluation in relation to a new justification in his/her decision argument. 4 of the 5 teachers who have determined that they are indecisive related to the nuclear power plant issue (ST3, ST4, ST9, ST11) have not used all of the justifications that they have used in their general evaluations, for their decision arguments or added new justifications in their decisions. 1 teacher has used all the justifications from his/her general evaluations also in his/her decision arguments and also added a new justification in his/her decision argument.

\section{Findings on the Resources that are Effective in the Decision-Making of the STs in Relation to SSIs}

The findings of the resources applied by the STs during the decision-making on socio-scientific issues are presented in table 7 .

Table 7. Resources used by science teachers in decision-making about socio-scientific issues

\begin{tabular}{llc}
\hline Theme & Code & $\mathrm{f}$ \\
\hline Scientific & Scientific resource & 15 \\
& Scientific data & 6 \\
Media & Newspaper & 8 \\
& Television & 8 \\
& Social Media & 5 \\
& Internet & 4 \\
Environment & Friend & 6 \\
& Family & 4 \\
\multirow{5}{*}{ Authority } & Movement & 1 \\
& Energy expert & 4 \\
& Scientist & 3 \\
\hline
\end{tabular}

Table 7 shows the resources that science teachers apply to make a decision, defend their views and refute a counter opinion. It is significant that most of the teachers' references that they apply while making a decision related to the nuclear power plant are scientific sources and numerical data $(f=15)$. In relation to this, T5 has stated:

...generally numeric results or scientific studies such as reports, etc. that are published are more significant for me. When I make my decision, I especially try to consider the results of the scientific studies...", and also ST9 has stated "I can say that scientific sources have a more positive effect in terms of persuasion and decision-making in today's environment where there is a high volume of 
information pollution. While making a decision, I always have a hard time. Reading published studies give me the possibility to consider the subject under a different light. I think it is effective in my decision making. I can best refute someone's objecting ideas this way...

statement, shows that in decision making or in refuting a contrary view the scientific data are more effective. Some of the teachers have stated that they use media outlets $(f=8)$ and television $(f=8)$, especially the newspapers and television when deciding on the subject. ST11:

I am always trying to catch the news hours. Or; as the nuclear is on the agenda, if there is a channel where this issue is discussed, I watch that channel, and there are generally programs that continue with a discussion. They give me an idea and definitely affect my decision making. Because in television programs they never gather people who have the same idea together. I like it better to listen to different views and synthesize these...

ST8 has stated:

...even though internet and social media cover us from every corner, I always follow the daily newspapers. Especially if the issues on the front burner are discussed or considered, they take my attention so much more. For that reason, even though I prefer scientific resources and data while making a decision, newspapers also affect the people...

and tried to take under consideration the role of the media during decision-making. ST9 has stated in a similar way:

In relation to the establishment of the nuclear power plant, I mostly read the scientific studies that are realized. It is an issue discussed on television programs, and there are mostly specialists in these programs.", I examine each of the two opinions. As it is not easy to make a decision on this matter, more than one resource is much more helpful. I will give an opinion to the people who don't think the same way as me following the resources where I got my information from.

and also provided some tips for the researchers and readers on how to refute the opposing opinion. Some of the STs $(\mathrm{f}=6)$ have stated that they are influenced by their friends' opinions under the environmental theme and emphasized the impact of the environment in their decision-making. Some of the STs have reported that an authority, for example, an energy expert $(\mathrm{f}=4)$, is effective in their decision-making process. ST7 has stated:

Energy experts can provide more detailed information on the nuclear power plant. As it is their area of specialization, they can put forth the risk factors related to the establishment or non-establishment of the nuclear power plant. I consider this as an alternative in healthy decision making...

\section{Discussion and Conclusion}

The purpose of this research in which the decisions of STs in relation to the establishment of a nuclear power plant in Sinop, which is also a problem in their life, is studied is to study if the decisions of teachers in relation to nuclear power plant reflect normative decision-making. The knowledge levels of science teachers about nuclear power plants are mostly found to be sufficient. It is believed that the reason for this situation is the fact that the science teachers are familiar with the issue and have sufficient knowledge to formulate an opinion about it as they work in Sinop. Although the subject of nuclear power plant is consistent with the context of the daily life of the teachers and it is related to science, it is a noteworthy conclusion that science teachers' knowledge levels are most of the time partially sufficient. When it is considered that most of the science teachers have 15 years and more or 6-10 years of professional experience, it would be expected from the STs to have a higher level of information. However, various researchers have also found out that the knowledge level of pre-service science teachers on the subjects such as nuclear power plants and its working principle is insufficient (Eş, et al., 2016; Kapici \& Ilhan, 2016; Özdemir \& Çobanoğlu, 2008) Within the context of this research, this step is considered as the "defining of the problem" step of the decision-making process. In this step, it is important for the teachers to respond to questions such as "What is nuclear energy? What is the operating principle of the nuclear power plants?" As a matter of fact, in order to make evaluations about the nuclear power plant, first, they must have information in relation to nuclear power plants. As a matter of fact, it is important that students / individuals have awareness and content knowledge about the SSIs in the decision-making process (Tekbiyik, 2015). During the definition step of the problem, the in-depth examination of the problem is significant in 
obtaining the best solution (Lunenburg, 2010). At this step, which is considered as a step of defining the problem of the decision-making process, it is determined that teachers do not have an in-depth knowledge of nuclear power plants.

In "generating alternatives" and "evaluating alternatives" steps of the decision-making process, it is expected from the STs to make determinations related to the negative and positive aspects of the nuclear power plants and make evaluations in relation to these factors. Science teachers evaluated the nuclear power plants socioscientific issue mostly with their economic and environmental dimensions. It has been found out that the evaluations made with economy dimension have different justifications such as energy, cost, external dependence and lifetime. It has also been found out that they can make determinations based on various reasons such as danger that would be caused by the wastes, environmental damage and radiation that the wastes would generate. It is possible to state that they have a multifaceted point of view in the economy and environment dimensions. On the other hand, science teachers made evaluations on social/cultural justifications less frequently. They have described these evaluations with the dangers and safety reasons against the public health and the personnel. Only one teacher has provided political considerations in his/her evaluation in relation to the nuclear power plants. The fact that STs can assess the nuclear power plants issue mostly through its economic, environmental, social/cultural dimensions suggests that they can take it under consideration partially through multifaceted aspects. As researchers realized with science teachers are limited (Kenar, 2013; Lee \& Yang, 2013), conclusions of a few studies realized with the teachers and pre-service science teachers that are known as the closest working group are similar to the conclusions of these researchers. Lee and Yang (2013) have found out that technology teachers in Taiwan mostly do not support the construction of nuclear power plants in Taiwan and they prefer to benefit from clean, renewable energy sources such as wind and sun. In the research, it has been found out that the teachers have cited the accident in Fukushima and the threats to the environment as justifications. In the research realized with pre-service science teachers by Atesanderson and Saracoğlu (2013), it has been found out that most of the pre-service teachers have positive thoughts in relation to nuclear energy in terms of generating electricity and energy and providing prestige. It has been concluded that the pre-service teachers who have negative considerations about nuclear energy have provided apprehensive answers because of problems such as possible serious accidents, cancer and radioactive leak. In the research that they have realized with pre-service science and social studies teachers, Kapici and Ilhan (2016) have concluded that the pre-service teachers with a positive point of view in the establishment of the nuclear power plant have made this decision because of the generation of high volume of energy, and the pre-service with a negative point of view in the establishment of the nuclear power plant have made their decision because of the fact that radiation emission will trigger global warming.

Socio-scientific issues include dimensions such as economics, environment, social/culture, policy factors and also ethics/morals and scientific explanations (Chang Rundgren \& Rundgren, 2010; Kolstø et al., 2006; Ratchliffe \& Grace, 2003). In this case, the notable result of the study is that the science teachers did not consider the scientific dimensions during their evaluations. The fact that STs can assess the nuclear power plants issue mostly through its economic, environmental, social/cultural dimensions suggests that they can take it under consideration partially through multifaceted aspects. On the other hand, it can be said that these are the details of their evaluations within these dimensions. It is believed that the reason for their detailed evaluation especially with these dimensions can be the fact that they approach to this problem that they face in the province they live more in terms of the issues that will influence their lives.

In "choosing an alternatives" step of the decision-making process, the teachers have been asked to express their decisions and justifications in relation to the establishment of a nuclear power plant in Sinop. It has been found out that the STs' decisions in relation to the establishment of a nuclear power plant in Sinop are mostly negative, less frequently indecisive, but there are also teachers who have positive points of view. It has been found out that the arguments used by the STs in expressing their decisions don't completely coincide with the justifications that they have stated in the "generating and evaluating of alternatives" step. In other words, all of the justifications taken under consideration by the teachers in their evaluations related to the issue have not been effective in their decision-making process. Another conclusion is that even though it is in a small number, teachers have included different justifications during their decision-making step, in addition to the ones that they have taken under consideration in the evaluation of alternatives step. Supports this result, Jho et al. (2013) was to examine the relationship of students' understanding of science knowledge, attitude and decision making on the issues of nuclear energy in Korea. Based on the results it was founded, students' understandings of science knowledge were significantly improved throughout the instruction. Howewer, they maintained similar attitude and decision making on the issue. Regarding the relationship of the three domains, attitude showed some degree of connection to decision making whereas science knowledge did not show a significant relationship to decision making. 
It is possible to understand the reasons behind the individuals' decisions about the SSI through theories directed at the decision-making process (Wu \& Tsai, 2007; 2011). For the individuals who are faced with the SSs, which by their nature allow the operation of decision-making processes, their previous experiences, practices or mental models will influence their decision-making (Fang et al., 2018). In this research, it has been found out that the fact that the science teachers' justifications that they have taken under consideration while presenting their decisions in relation to the nuclear power plants don't coincide with the justifications that they have taken under consideration while making evaluations in relation to the matter shows that they cannot reflect the normative decision-making process in their decisions. This conclusion can be interpreted as the teachers making a decision in relation to SSIs are affected by different factors other than knowledge. As a matter of fact, teachers who have been able to evaluate the positive aspects of the issue have been able to ignore these justifications while making their decisions. The normative decision-making theory considers the decision-making process as an analytical process that starts with the definition of the problem and ends with the decision (Germeijs \& De Boeck, 2003; Kortland, 1996). Chang Rundgren and Rundgren (2010) draw attention to the fact that decisions on SSIs are influenced by values and personal experiences other than knowledge. While Fleming (1986a) emphasizes the importance of personal experience in decision-making in relation to SSIs; Fleming (1986b) and Bell and Lederman (2003) consider the importance of ethics/morals in the decision-making processes of the individuals in relation to SSIs. Albe (2008) has taken under consideration the importance of personal experience, knowledge and values during the decision-making process and stated that epistemological thoughts are effective in decision-making. Kilinc et al. (2013) stated that the reliability of information sources, the evaluation of the data, the values, prejudices and the cultural variables are effective in the decision-making process. However, developing decision-making skills which are one of the purposes of science education, science teachers will have to consider applications that take under consideration the socio-scientific issues. In this case, the teachers will be expected to structure the education process in a way which will require analytical decision-making. A significant factor that should be taken under consideration here is that the participants' views related to SSIs such as chicken meat, abortion, nuclear power plant, consumption of GMOs can be studied through questions like "What do you think about the nuclear power plants?". "What do you think about the nuclear power plant? What are your thoughts on the establishment of the nuclear power plant?". These generic expressions are surely directed to the participants who have sufficient information to make interpretations on the issue. In class applications, students consider the issue from different angles, and they are expected to make a decision following a discussion. But, when these issues are taken under consideration in terms of the definition of the problem step which is the first step of the decision-making process, they are very generic issues where it is difficult to draw a line. The good definition of the problem statement is significant in making an analytical decision. Hence, while making a decision, the factors that are presented in the problem should be taken under consideration. When we take the nuclear power plant issue under consideration, it may make a contribution to operate the decision-making process, to present data such as the yearly energy need of our country, how much of this energy could be obtained from which resources, production costs of the renewable energy and nuclear energy and also providing data for the other dimensions and to provide the significance of the criteria in this direction, while presenting the economic dimension of the problem statement. As a matter of fact, it is possible to propose the configuration of the problem statement related to the SSIs in order to lessen the effect of the factors such as, lives, values and mental models of the individuals that will prevent the analytical decision, on the decision-making process.

The results of this research also cover the fact that when STs need to make a decision on socio-scientific issues, the resources that they apply are mostly scientific resources, media resources such as newspapers, TV and social media, friends or authorities in relation with the issue. The access of the STs to the information through accurate and reliable resources will affect the decision-making process. The fact that they prefer to access the information through resources other than scientific ones, such as newspaper, TV, social media and friends provide clues in relation to the factors that affect their decision-making.

\section{Recommendations}

For future researchers, it can be suggested to examine the processes that are implemented through problem statement in which SSIs are presented with structure or without structure. In addition, more detailed findings can be reached by asking the teachers why they do not include the arguments in the decision of the factors mentioned during the evaluation of the alternatives. It is possible to discuss the suitability of teachers' classroom practices in developing students' decision-making skills by conducting researchers with a focus on how teachers are taking the SSIs under consideration in their classroom. 


\section{References}

Acar, O., Turkmen, L., \& Roychoudhury, A. (2010) Student difficulties in socio-scientific argumentation and decision-making research findings: Crossing the borders of two research lines. International Journal of Science Education, 32(9), 1191-1206. doi: 10.1080/09500690902991805

Albe, V. (2008). Students' positions and considerations of scientific evidence about a controversial socioscientific issue. Sci \& Educ, 17, 805-827.

Ates, H., \& Saracoglu, M. (2016). Pre-service science teachers' views about nuclear energy with respect to gender and university providing instruction. Science Education International, 27(2), 238-252.

Baker, D., Bridges, D., Hunter, R., Johnson, G., Krupa, J., Murphy, J., \& Sorenson, K. (2001). Guidebook to decision-making methods. Department of Energy, USA. Retrieved on 3 February 2019 http://emiweb.inel.gov/Nissmg/Guidebook_2002.pdf

Barrue, C., \& Albe, V. (2013). Citizenship education and socioscientific issues: implicit concept of citizenship in the curriculum, views of french middle school teachers. Science \& Education, 22 (5), 1089-1114.

Bell R.L., \& Lederman N.G. (2003) Understandings of the nature of science and decision-making on science and technology based issues. Sci Educ, 87, 352-377.

Bogden, R. C., \& Biklen, S. K. (2007). Qualitative research for education: An introduction to theories and methods. Boston: Allyn and Bacon. doi: 10.1002/sce.10063.

Bossér, U., Lundin, M, Lindahl, M., \& Linder, C. (2015). Challenges faced by teachers implementing socioscientific issues as core elements in their classroom practices. European Journal of Science and Mathematics Education, 3(2), 159-176.

Cansiz, N., \& Cansız, M. (2015). Views and knowledge of preservice science teachers about nuclear power plants. International Journal on New Trends in Education and Their Implications, 6(2), 216-224.

Chang, S. N., \& Chiu, M. H. (2008). Lakatos' scientific research programmes as a framework for analysing informal argumentation about socioscientific issues. International Journal of Science Education, 30, 1753-1773.

Chang Rundgren, S. N., \& Rundgren, C. J. (2010). SEE-SEP: from a separate to a holistic view of socioscientific issues. Asia-Pacific Forum on Science Learning and Teaching, 11(1), 1-24.

Creswell, J. W. (2007). Qualitative inquiry and research design: choosing among five approaches (2th Edition). USA: Sage Publications.

Eggert, S., \& Bögeholz, S. (2010). Students' use of decision-making strategies with regard to socioscientific issues: an application of the rasch partial credit model. Science Education, 94(2), 230-258.

Eggert, S., Ostermeyer, F., Hasselhorn, M., \& Bögeholz, S. (2013). Socioscientific decision making in the science classroom the effect of embedded metacognitive instructions on students' learning outcomes. Education Research International, 2013, 1-12.

Ercan, O., Ural, E., \& Tekbiyık, A. (2015). Pre-service teachers' attitudes towards nuclear energy and the effect of Fukushima nuclear disaster on their attitudes. The International Journal of Social Sciences and Humanities Invention, 2(11), 1669-1678.

Eş, H., Işık Mercan, S., \& Ayas, C. (2016). A new socio-scientific issue for Turkey: Life with nuclear. Turkish Journal of Education, 5(2), 47-59.

Evren Yapıcıŏlu, A., \& Aycan, Ş. (2018). Pre-service science teachers' decisions and types of informal reasoning about the socioscientific issue of nuclear power plants. Educational Policy Analysis and Strategic Research, 13(1), 31-53.

Fang, C., Hsu, Y. S., \& Lin, S. S. (2018). Conceptualizing socioscientific decision making from a review of research in science education. International Journal of Science and Mathematics Education, 1-22.

Fleming R (1986a) Adolescent reasoning in socio-scientific issues, Part I: Social cognition. Journal of Research in Science Teaching, 23, 677-687.

Fleming R (1986b) Adolescent reasoning in socio-scientific issues, Part II: Nonsocial cognition. Journal of Research in Science Teaching,23, 689-698.

Gauld, C. F. (2005). Habits of mind, scholarship and decision making in science and religion. Science \& Education, 14(3), 291-308.

Gay, L. R., Mills, G. E., \& Airasian, R. (2006). Educational Research: Competencies for Analysis and Applications. Upper Saddle River, NJ: Pearson/Merrill/Prentice Hall.

Germeijs, V., \& De Boeck, P. (2003). Career indecision: Three factors from decision theory. Journal of Vocational Behavior, 62, 11-25.

Hansson, S. O. (2005). Decision theory: a brief introduction. The royal institute of technology. department of philosophy and the history of technology, Stockholm. Retrieved from on 8 April 2013 http://www.infra.kth.se/ soh/decisiontheory.pdf 
Hogarth, R. M. (2005). Deciding analytically or trusting your intuition? The advantages and disadvantages of analytic and intuitive thought. In: T. Betsch \& S. Haberstroh (Eds.), The Routines of Decision Making (pp. 67-82). Mahwah: Lawrence Erlbaum Associates.

Hong, J., \& Chang, N. (2004). Analysis of Korean high school students' decision-making processes in solving a problem involving biological knowledge. Research in Science Education, 34(1), 97-111.

Jho, H., Yoon, H.G., \& Kim, M. (2014). The relationship of science knowledge, attitude and decision making on socio-scientific issues: The case study of students' debates on a nuclear power plant in Korea. Science \& Education, 23, 1131-1151.

Jime'nez-Aleixandre, M. P. (2002). Knowledge producers or knowledge consumers? Argumentation and decision making about environmental management. International Journal of Science Education, 24(11), 1171-1190.

Jonassen, D. H. (2012). Designing for decision making. Educational Technology Research and Development, 60(2), 341-359.

Kapici H.O., \& Ilhan G.O. (2016). Pre-service teachers' attitudes toward socio-scientific issues and their views about nuclear power plants. Journal of Baltic Science Education, 15, 642-652.

Kenar, I. (2013). Nuclear energy reality in Turkey and the attitude of the science teachers towards the issue. The Anthropologist,16, (1-2), 153-165, doi: 10.1080/09720073.2013.11891344.

Kılınç, A., Stanisstreet, M., \& Boyes, E. (2008). Turkish Students' Ideas about Global Warming. International Journal of Environmental and Science Education, 3(2), 89-98.

King, P. M., \& Kitchener, K. S. (2004). Reflective judgment: Theory and research on the development of epistemic assumptions through adulthood. Educational Psychology, 39, 5-18.

Kolstø, S.D. (2001). To trust or not to trust, pupils' ways of judging information encountered in a socioscientific issue. International Journal of Science Education, 23, 877-901.

Kolstø, S. D., Bungum, B., Arnesen, E., Isnes, A., Kristensen, T., Mathiassen, K., Mestad, I., Quale, A., Tonning, A. S. V., \& Ulvik, M. (2006). Science students' critical examination of scientific information related to socioscientific issues. Science Education, 90(4), 632-655.

Kortland, K. (1996). An STS case study about students' decision making on the waste issue. Science Education, 80(6), 673-689.

Lee, H., \& Witz, K. G. (2009) Science teachers' inspiration for teaching socio-scientific 1ssues: Disconnection with reform efforts. International Journal of Science Education, 31(7), 931-960. doi: $10.1080 / 09500690801898903$

Lee, L. S., \& Yang, H. C. (2013). Technology teachers' attitudes toward nuclear energy and their implications for technology education. Paper presented at the Pupils' Attitude towards Technology (PATT). Technology Education for the Future: A Play on Sustainability Conference, New Zealand.

Levinson, R. (2006). Towards a theoretical framework for teaching controversial socio-scientific issues. International Journal of Science Education, 28(10), 1201- 1224.

Levinson, R. (2008). Promoting the role of the personal narrative in teaching controversial socio-scientific issues. Science \& Education, 17, 855-871.

Lipshitz, R., Klein, G., Orasanu, J., \& Salas, E. (2001). Focus article: taking stock of naturalistic decision making. Journal of Behavioral Decision Making, 14(5), 331.

Lunenburg, F. C. (2010). The decision making process. National forum of educational administration and supervision journal, 27(4), 1-12.

Merriam, S. B. (2009). Qualitative research: A guide to design and implementation (3 edition). San Francisco: Jossey Bass.

Miles, M. B., \& Huberman, A. M. (1994). Qualitative data analysis: An expanded sourcebook. Thousand Oaks, CA: Sage Publications.

Ministry of National Education of Turkey (MoNE). (2018). Science curriculum (3rd-8th grades) of elementary institutions (primary and secondary schools). Ankara: Board of Education.

Özdemir, N. (2014). How will it affect attitudes to discuss socio-scientific issues within the framework of socioscientific principles? Nuclear energy. Turkish Studies, 9(2), 1197-1214.

Özdemir, N., \& Çobanoğlu, E. O. (2008). Prospective teachers' attitudes towards the use of nuclear energy and the construction of nuclear plants in turkey. Hacettepe University Journal of Education, 34, 218-232.

Öztürk, N., \& Yenilmez Türkoğlu, A. (2018). Öğretmen adaylarının akran liderli tartışmalar sonrası çeşitli sosyo-bilimsel konulara ilişkin bilgi ve görüşleri [Pre-service science teachers' knowledge and views about several socio-scientific issues after peer-led discussions]. Illkögretim Online [Elementary Education Online] 17(4), 2030-2048.

Patronis, T., Potari, D., \& Spiliotopoulo, V. 1999. Students' argumentation in decision-making on a socioscientific issue: implications for teaching. International Journal of Science Education, 21(7), 745-754.

Presley, M.L., Sickel, A.J., Muslu, N., Merle-Johnson, D., Witzig, S.B., Izci, K., \& Sadler, T.D. (2013). A framework for socio-scientific issues based education. Science Educator,22, 26-32. 
Ramana, M. V. (2011). Nuclear power and the public. Bulletin of the Atomic Scientists, 67(4), 43-51.

Ratcliffe, M. (1997). Pupil decision-making about socio-scientific issues within the science curriculum. International Journal of Science Education, 19(2), 167-182.

Ratcliffe, M., \& Grace, M. (2003). Science education for citizenship. Maidenhead: Open University Press.

Raeva, D., Dijk, E., \& Zeelenberg, M. (2011). How comparing decision outcomes affects subsequent decisions: The carry-over of a comparative mind-set. Judgment and Decision Making, 6(4): 343-350.

Ratner, R. K., \& Herbst, K. C. (2004). When good decisions have bad outcomes: The impact of affect on switching behavior. Organizational Behavior and Human Decision Processes, 96, 23-37.

Sadler, T. D. (2004). Informal reasoning regarding socioscientific issues: A critical review of research. Journal of Research in Science Teaching, 41(5), 513- 536.

Sadler, T. D., \& Zeidler, D. L. (2004). The morality of socioscientific issues: Construal and resolution of genetic engineering dilemmas. Science Education, 88, 4-27.

Sadler, T. D. ve Zeidler, D. L. (2005). Patterns of informal reasoning in the context of socioscientific decision making. Journal of Research in Science Teaching, 42(1), 112-138.

Sadler, T. D., \& Donnelly, L. A. (2006). Socioscientific Argumentation: The effects of content knowledge and morality. International Journal of Science Education, 28 (12), 1463-1488.

Sadler, T. D., Barab, S. A., \& Scott, B. (2007). What do students gain by engaging in socio-scientific inquiry? Research in Science Teaching, 37(4), 371-391.

Sadler, T.D. (2009). Situated learning in science education: Socio-scientific issues as contexts for practice. Studies in Science Education, 45,1-42.

Svenson, O. (1996). Decision making and the search for fundamental psychological regularities: what can be learned from a process perspective? Organizational Behavior and Human Decision Processes, 65(3), $252-267$.

Tekbiyik, A. (2015). The use of Jigsaw collaborative learning method in teaching socioscientific issues: The case of nuclear energy. Journal of Baltic Science Education, 14(2), 237-253.

Topcu, M. S., Sadler, T. D., \& Y1lmaz-Tuzun, Ö. (2010). Preservice science teachers' informal reasoning about socioscientific issues: The influence of issue context. International Journal of Science Education, 32(18), 2475-2495.

Wu, Y.-T., \& Tsai, C.-C. (2007). High school students' informal reasoning on a socio-scientific issue: Qualitative and quantitative analyses. International Journal of Science Education, 29(9), 1163-1187.

Wu, Y.-T., \& Tsai, C. C. (2011). High school students' informal reasoning regarding a socio-scientific issue, with relation to scientific epistemological beliefs and cognitive structures. International Journal of Science Education, 33(3), 371-400.

Wu, Y-T., \& Tsai, C. C. (2012). Perspectives on Scientific Argumentation. Theory, Practice and Research (Edt. Khine, M. S.). The effects of university students' argumentation on socio-scientific issues via on-line discussion in their informal reasoning regarding this issue (pp.221-234). Dordrecht: Springer.

Yang, F.-Y., \& Anderson, O. R. (2003). Senior high school students' preference and reasoning modes about nuclear energy use. International Journal of Science Education, 25 (2), 221-244.

Yener, D., Aksüt, P., \& Somuncu Demir, N. (2017). Science teacher candidates' attitudes and opinions concerning nuclear power plants: A nuclear research reactor trip. International Journal of Environmental \& Science Education, 12(5), 1283-1297.

Zeidler, D. L., Sadler, T. D., Simmons, M. L., \& Howes, E. V. (2005). Beyond STS: A research-based framework for socioscientific issues education. Science Education, 89(3), 357-377.

Zeidler, D. L. (2014). Socioscientific issues a curriculum emphasis: theory, research and practice. In S.K. Abell \& N. G. Lederman (Eds.), Handbook of research on science education (pp.697-725). Mahwa, NY: Routledge, Taylor and Francis.

Zohar, A., \& Nemet, F. (2002). Fostering students' knowledge and argumentation skills through dilemmas in human genetics. Journal of Research in Science Teaching, 39(1), 35-62.

\section{Author Information}

\begin{tabular}{ll}
\hline Nurhan Ozturk & Esra Bozkurt Altan \\
Sinop University & Sinop University \\
Education Faculty, Department of Science Education & Education Faculty, Department of Science Education \\
Sinop/Turkey & Sinop/Turkey \\
Contact e-mail: nurhanozturk@ sinop.edu.tr & \\
\hline
\end{tabular}

